\title{
CHARACTERIZATION OF BACTERIAL ISOLATES FOR SUSTAINABLE RICE BLAST CONTROL ${ }^{1}$
}

\author{
BÁRBARA ESTEVAM DE MELO MARTINS ${ }^{2}$, AMANDA ABDALLAH CHAIBUB ${ }^{3}$, MARCIO VINICIUS DE \\ CARVALHO BARROS CORTÊS ${ }^{4}$, VALÁCIA LEMES DA SILVA LOBO ${ }^{4}$, MARTA CRISTINA CORSI DE FILIPPI ${ }^{4 *}$
}

\begin{abstract}
Rice blast (Magnaporthe oryzae) limits rice (Oryza sativa) grain yields worldwide. The objective of this investigation was to morphologically, biochemically, and molecularly characterize six bacterial isolates, BRM 32109, BRM 32110, BRM 32111, BRM 32112, BRM 32113, and BRM 32114, and to determine their potential as antagonists to M. oryzae. Morphological characterization was based on colony formation and color, Gram staining, and fluorescent pigment production. Biochemical studies were based on cellulase, chitinase, phosphatase, indoleacetic acid, and siderophore production, as well as biofilm formation. The molecular identification used specific primers for PCR amplification of the 16S rRNA region, followed by sequencing. The antagonism studies involved three experiments, which had randomized designs. Two of them were conducted in laboratory conditions, pairing bacterial colonies and M. oryzae, using bacterial filtrates, and the third was conducted in greenhouse conditions. BRM 32111 and BRM 32112 were identified as Pseudomonas sp., BRM 32113 as Burkholderia sp., BRM 32114 as Serratia sp., and BRM 32110 and BRM 32109 as Bacillus spp. BRM 32112, BRM 32111, and BRM 32113 inhibited the colony of M. oryzae by 68\%, $65 \%$, and $48 \%$, respectively. The bacterial suspensions of the BRM 32111, BRM 32112, and BRM 3212 filtrates suppressed leaf blast by 81.0, 79.2, and 66.3\%, respectively. BRM 32111 and BRM 32112 were determined to be antagonists of $M$. oryzae and were found to solubilize phosphate, produce siderophores and cellulose, form biofilms, and suppress leaf blast. These isolates should be further investigated as potential biological control agents for leaf blast control.
\end{abstract}

Keywords: Oryza sativa. Biological control. Antagonism. Pyricularia oryzae.

\section{CARACTERIZAÇÃO DE ISOLADOS BACTERIANOS PARA O CONTROLE SUSTENTÁVEL DA BRUSONE DO ARROZ}

RESUMO - A brusone (Magnaporthe oryzae) limita a produção do arroz (Oryza sativa), no Brasil e no mundo. Os objetivos foram caracterizar seis isolados bacterianos morfológica, bioquímica e molecularmente, e determinar seu potencial como antagonistas a M. oryzae. Utilizaram se os isolados bacterianos BRM 32109, BRM 32110, BRM 32111, BRM 32112, BRM 32113 e BRM 32114. Avaliou-se o formato e a cor das colônias, coloração de Gram e produção de pigmentos fluorescentes. Identificou-se a produção de celulase, quitinase, fosfatase, ácido indolacético, sideróforo e formação de biofilme. A identificação molecular foi realizada utilizando-se oligonucleotídeos iniciadores específicos para amplificação por PCR da região 16S rRNA, seguidos de sequenciamento. Os dois ensaios envolvendo antagonismo foram realizados em laboratório, em delineamento inteiramente casualizados, um com cultivo pareado entre isolado de bactérias e M. oryzae, e outro com filtrados bacterianos. Um terceiro ensaio em casa de vegetação para avaliar a supressão da brusone. Identificou-se Pseudomonas sp. (BRM 32111 e BRM 32112), Burkholderia sp. (BRM 32113), Serratia sp. (BRM 32114) e Bacillus spp. (BRM 32110 e BRM 32109 ). Os isolados BRM 32112, BRM 32111 e BRM 32113 inibiram o crescimento da colônia de $M$. oryzae em 68, 65 e 48\%, respectivamente. As suspensões bacterianas BRM 32111, BRM 32112 e seu filtrado suprimiram a brusone foliar em 81,0, 79,2 e 66,3\%, respectivamente. BRM 32111 e BRM 32112 são antagonistas ao fungo M. oryzae, solubilizam fosfato, produzem sideróforos, celulase e biofilme e suprimiram a brusone foliar, mostrando-se potenciais agentes biológicos para o controle da brusone foliar.

Palavras-chave: Oryza sativa. Controle biológico. Antagonismo. Pyricularia oryzae.

${ }^{2}$ Graduate Program in Agronomy, Universidade Federal de Goiás, Goiânia, GO, Brazil; barbara_estevam@hotmail.com - ORCID: 00000001-5092-6897.

${ }^{3}$ Graduated Program in Plant Pathology, Universidade Federal de Brasília, Distrito Federal, DF, Brazil; amandachaibub@gmail.com ORCID: 0000-0002-4025-668X.

${ }^{4}$ Agricultural Microbiology Laboratory, Embrapa Arroz e Feijão, Santo Antônio de Goiás, GO, Brazil; marcio.cortes@embrapa.br ORCID: 0000-0002-2342-8072, valacia.lobo@embrapa.br - ORCID: 0000-0001-9810-3689, cristina.filippi@embrapa.br - ORCID: 00000003-1676-8164.
} 


\section{INTRODUCTION}

Rice (Oryza sativa L.), a primary staple food for half of the global population and the source of approximately $20 \%$ of many peoples' daily caloric intake, is mainly composed of carbohydrates, calcium, iron, thiamine, and vitamin E (RATHNA et al., 2019). According to the Food and Agricultural Organization of the United Nations (FAO) and Ricepedia (2020), global rice demands are expected to rise from 496 million tons in 2020 to 555 millions tons in 2035 (http://ricepedia.org/challenges/foodsecurity). While a great deal of scientific research has previously focused on improving and protecting rice production, it continues to be affected by numerous biotic stresses throughout its growth and development. Among these, rice blast caused by Magnaporthe oryzae B. C. Couch (anamorphPyricularia oryzae Cavara.) is a major yield-limiting pathogen, that can result in losses of $100 \%$ in susceptible rice cultivars (TALBOT, 2003, PRABHU; FARIA; ZIMMERMANN, 1989). Yield losses could be reduced by preventive measures, such as integrating genetic resistance, cultural practices, and chemical controls. It is common practice for example, that pesticides are excessively applied close to harvest time to avoid the loss of rice panicles, but these practices are unsustainable, not cost effective, and have negative impacts for humans and the environment (ASIAH et al., 2019). Overrall, chemical controls are often utilized in an abusive manner affecting the quality of the product and causing harm to the environment. The global crop protection market showed a growth rate of $3.8 \%$ from 2001 to 2016, and while from 2014-2016 the trend line declined globally, in Latin America it remained constant (NISHIMOTO, 2019).

In recent years, the search for alternative control measures has been intensified, and this has included biocontrols as a significant part of integrated rice blast management. The rhizosphere is found at the soil-root interface, where several microorganisms proliferate, such as plant growth promoted bacteria (PGPR) (MOREIRA; SIQUEIRA, 2002). PGPR interact with plants, resulting in the promotion of growth as a direct effect, while inderctly they elicit biochemical and molecular defense responses within the plant. The same PGPRs can also be antagonists to plant pathogens as they can secrete compounds that can affect pathogen growth and reproduction (FILIPPI et al., 2011).

There have been many previous investigations of rice plant endophitics and rhizosphere microorganisms that have antagonistic activities against rice pathogens (WALITANG et al., 2019, WIDIANTINI; HERDIANSYAH; YULIA, 2017). Most of these investigations have been conducted under laboratory conditions. This could be a limitation with respect to developing stable biological agents for application in field conditions.
As a result of this, currently there are few, if any, biological control options for rice diseases (HASSAN; HOSSEIN; HOSSEIN, 2019).

The main objectives of this investigation were the morphological, biochemical, and molecular characterizations of six bacterial isolates and the identification of potential antagonists, both in vitro and in vivo, for Magnaporthe oryzae.

\section{MATERIALS AND METHODS}

The isolates utilized in the present study are preserved on sterilized filter paper discs in the Embrapa Rice and Bean Multifunction Microorganism and Fungi Collection. The M. oryzae isolate BRM 10900 was obtained from leaf lesions of the cultivar BRS Primavera. Six bacterial isolates, designed by the collection codes (BRM 32109, BRM 32110, BRM 32111, BRM 32112, BRM 32113, and BRM 32114) were obtained from the rhizospheres and phyllospheres of healthy rice plants (in a commercial field) that were selected by Filippi et al. (2011) and Pereira Filho (2013). The bacterial isolates were cultivated in Petri dishes containing culture medium 523 (sucrose $10 \mathrm{~g}$, hydrolyzed casein $8 \mathrm{~g}$, yeast extract $4 \mathrm{~g}, \mathrm{~K}_{2} \mathrm{HPO}_{4} 2 \mathrm{~g}, \mathrm{MgSO}_{4} \cdot 7 \mathrm{H}_{2} \mathrm{O}$ $300 \mathrm{mg}$, agar-agar $20 \mathrm{~g}$, and distilled $\mathrm{H}_{2} \mathrm{O}, 1000 \mathrm{~mL}$ ) (KADO; HESKETT, 1970) in triplicate, and incubated for $24 \mathrm{~h}$ at $28{ }^{\circ} \mathrm{C}$. The morphological, biochemical, genetic, and antagonistic characteristics of each bacterial strain were then assessed.

\section{Morphological characterization}

The colony characteristics surface, form, margins, and coloration of the gram staining, were observed using a compound microscope at $100 \times$ magnification, following the methods described by Benson (2002).

\section{Production of fluorescent pigment}

The bacterial isolates were each cultivated in Petri dishes containing Kings B medium (protease 20 g, $\mathrm{K}_{2} \mathrm{HPO}_{4} .3 \mathrm{H}_{2} \mathrm{O}, 2.5 \mathrm{~g}, \mathrm{MgSO}_{4} .7 \mathrm{H}_{2} \mathrm{O}, 6 \mathrm{mg}$, glycerol $15 \mathrm{~mL}$, agar-agar $15 \mathrm{~g}$, distilled $\mathrm{H}_{2} \mathrm{O}$, $1000 \mathrm{~mL}$ ), for $24 \mathrm{~h}$ at $28{ }^{\circ} \mathrm{C}$. They were then examined under ultraviolet light $(\lambda=365 \mathrm{~nm})$ for the presence or absence of fluorescent pigments (MARIANO et al., 2004), when compared with a no pigment producer isolate.

\section{Biochemical characterization}

Cellulase: According to Strauss et al. (2001), the tripticasein soybean agar (TSA) culture medium was supplemented with $10 \mathrm{~g} \mathrm{~L}^{-1}$ of cellulose. The cultures for each bacterial strain were incubated for five days at $28-30{ }^{\circ} \mathrm{C}$, and later saturated with $0.03 \%$ 
red Congo solution for $10 \mathrm{~min}$, and then washed with $\mathrm{NaCl}$ to reveal transparent halos around the colonies, indicating yes or no cellulose production.

Indole acetic acid (IAA): According to Bric, Bostock and Silverstone (1991) and Cattelan (1999), TSA culture medium was diluted to $1 / 10$ and enriched with $5 \mathrm{mM}$ de L-tryptophan $\left(1021 \mathrm{~g}^{-1} \mathrm{~L}^{-1}\right)$. After $24 \mathrm{~h}$, the colonies for each bacterial strain were covered with a sterilized nitrocellulose membrane, and incubated at $28{ }^{\circ} \mathrm{C}$, for $24 \mathrm{~h}$. The membrane was then transferred to another plate, and saturated with Salkowski's solution (GORDON; WEBER, 1951), and incubated at room temperature for up to $2 \mathrm{~h}$, and then the changes (yes or no) in the membrane colors were observed.

Phosphate production: According to Sylvester -Bradley et al. (1982), the TSA medium was diluted to $1 / 10$ with the addition of a phosphorus source $\left(\mathrm{CaHPO}_{4}\right)$. A fine precipitate was obtained by mixing a solution of $50 \mathrm{~mL} \mathrm{~K}{ }_{2} \mathrm{HPO}_{4}(0.57 \mathrm{M})$ with $100 \mathrm{~mL}$ of $\mathrm{CaCl}_{2}(0.90 \mathrm{M})$, and adding it to $850 \mathrm{~mL}$ of $1 / 10$ TSA. The solution and culture medium were autoclaved separately, the medium's $\mathrm{pH}$ was adjusted to 7.0, and the colonies were incubated at 28 $-30{ }^{\circ} \mathrm{C}$ for 2 days. The isolates were qualitatively detected as phosphate solubilizer when a halo formed around the bacterial colonies.

Siderophore production: Isolates for each bacterial strain were cultivated in $50 \mathrm{~mL}$ Erlenmeyer flasks containing $10 \mathrm{~mL}$ of the liquid culture medium tryptic soy (TSL1/10) and incubated for $24 \mathrm{~h}$ at $28{ }^{\circ} \mathrm{C}$, with constant agitation. Next, cell suspensions were centrifuged at $12000 \mathrm{rpm}$ for $10 \mathrm{~min}$. One milliliter of supernatant was transferred to a culture tube and $1 \mathrm{ml}$ of the indicator solution chrome azurol $\mathrm{S}$ (CAS) was added. The production of siderophores was indicated when the solution color changed to blue (CATTELAN, 1999).

Chitinase production: According to Hsu and Lockwood (1975), a culture medium that contains chitin as the only carbon source (chitin, $4 \mathrm{~g}$; $\mathrm{K}_{2} \mathrm{HPO}_{4}, 0.7 \mathrm{~g} ; \mathrm{KH}_{2} \mathrm{PO}_{4}, 0.3 \mathrm{~g} ; \mathrm{MgSO} 4.5 \mathrm{H} 2 \mathrm{O}$, $0.5 \mathrm{~g} ; \mathrm{FeSO}_{4.7} \mathrm{H}_{2} 0,0.01 \mathrm{~g} ; \mathrm{ZnSO}_{4}, 0.001 \mathrm{~g} ; \mathrm{MnCl}_{2}$, $0.001 \mathrm{~g}$; agar, $20.0 \mathrm{~g}$ and $1000 \mathrm{~mL}$ of ionized water) was utilized to qualitatively detect halos that formed around the colonies, to indicate chitinase production.

Biofilm formation: According to Mathur et al. (2006), after cultivating the bacterial colonies on culture medium 523, they were transferred to Petri dishes containing Congo Red Agar (CRA). Plates were then incubated at $26^{\circ} \mathrm{C}$ for $24-48 \mathrm{~h}$. Then, the black colonies with a dry crystalline consistency were qualitatively identified as the biofilm producers.

\section{Genetic characterization}

DNA extraction and amplification of $16 \mathrm{~S}$ rRNA region: Bacterial colonies of each isolate were grown on solid 523 medium for $48 \mathrm{~h}$. DNA was extracted according to $\mathrm{Li}$ and Bouer (1995), quantified by spectrophotometer (Nano Drop ${ }^{\circledR}$ ND$2000 \mathrm{UV}-\mathrm{Vis}$, at $260 \mathrm{~nm}$ wavelength) to determine the impurity. The total reaction volume was of $25 \mu \mathrm{L}$ (1 $\mu \mathrm{L}$ of DNA $25 \mu \mathrm{M}, 1 \mu \mathrm{L}$ of forward primer $25 \mu \mathrm{M}, 1 \mu \mathrm{L}$ of reverse primer $25 \mu \mathrm{M}, 5 \mu \mathrm{L}$ of Master Mix, $1 \mu \mathrm{L}$ of Q-solution, $1 \mu \mathrm{L}$ of sterile water MilliQ). The forward primer was F984 (AACGCGAAGAACCTTAC), and the reverse primer was R1492 (TACGG(C/T) TACCTTGTTACGACTT) (HEUER et al., 1997). Later, the reaction products $(10 \mu \mathrm{L})$ were then run using electrophoresis on $1.5 \%$ agarose gels $(\mathrm{p} / \mathrm{v})$, and the bands were observed in a photo documenter (Universal Hood II, Bio-Rad). Images were captured using the Quantity One (Bio-Rad) software.

Sequencing A BigDye ${ }^{\circledR}$ Terminator Cycle Sequencing kit (Life Technologies, USA, used according to the manufacture guidelines) in combination with the model ABI 3500 Genetic Analyzer atomized sequencing system, were utilized. For the sequencing reactions, $20 \mathrm{ng}$ of the purified PCR product with cyclase, and the reaction products were transferred to a sequencing plate with 96 cavities to be purified. The samples were denatured for $5 \mathrm{~min}$ at $95{ }^{\circ} \mathrm{C}$, and then stored at $4{ }^{\circ} \mathrm{C}$ in the dark, until the samples were injected into an ABI 3500 Genetic Analyzer atomized system. The DNA sequences were analyzed utilizing the BLASTn (Basic Local Alignment Search Tool - version 2.215 of BLAST 2.0) program available on the NCBI site (http://www.ncbi.nlm.nih.gov/blast/), developed by the National Center for Biotechnology Information (ALTSCHUL et al., 1990). The bases of low-quality sequences were removed using the Bio Edit Sequence Alignment Editor.

Data analysis: Principal component analysis (PCA) was performed to study the correlation among the biochemical characteristics (production of IAA, phosphatases, siderophores, chitinase, solubilization of phosphate, and formation of biofilms) and the diversity of bacteria isolates utilized in the present study. All variables were normalized using the presence or absence of proper vectors in the correlation matrix, as well as the variance of the percentage explained by each component. The PCA was calculated using the PAST 3 software (HAMMER; HARPER; RYAN, 2001).

\section{Antagonism characterization}

Dual plate: The bacteria were cultivated in Petri dishes containing culture medium 523 at $28^{\circ} \mathrm{C}$ for $24 \mathrm{~h}$. Then a suspension adjusted to $540 \mathrm{~nm}$, corresponding to $10^{8}$ ufc $\mathrm{mL}^{-1}$ was prepared, according to Dennis and Webster (1971). M. oryzae (BRM 10900) was cultivated in Petri dishes containing PDA for seven days at $28{ }^{\circ} \mathrm{C}$. The assay conducted included seven treatments (T1-BRM 32111, T2-BRM 32113, T3-BRM 32114, T4-BRM 
32110, T5-BRM 32109, and T6-BRM 32112) and one control, using a completely randomized design and three replications. A $5 \mathrm{~mm}$ disc of $M$. oryzae mycelium was transferred to the central part of a Petri dish containing PDA. Twenty microliters of the bacterial suspension were distributed at four equidistant points. The plates were then incubated at $28{ }^{\circ} \mathrm{C}$, under continuous fluorescent light, and those containing only mycelial discs of $M$. oryzae were used as the controls. Ten days after incubation, the radial growth of the pathogen colony in each treatment was measured and compared with the control.

Filtrate thermostability: The bacterial suspension was prepared in water and adjusted to $540 \mathrm{~nm}\left(10^{8} \mathrm{ufc}^{-1} \mathrm{~mL}^{-1}\right)$, according to Dennis and Webster (1971)

Bacterial cell filtrate: One microliter of each bacterial cell suspension was then transferred to Erlenmeyer flasks containing $250 \mathrm{ml}$ of Simmons culture medium (SIMMONS, 1926), with the following modifications: citrate was substituted by $0.1 \mathrm{~g} \mathrm{~L}^{-1}$ of glucose as the only carbon source, and incubated in an orbital agitator at $150 \mathrm{rpm}$, in the dark for seven days at $25^{\circ} \mathrm{C}$.

Filtration: the liquid part was filtered twice, first with filter paper $(0.45 \mu \mathrm{m})$, utilizing a Buchner funnel $240 \mathrm{~mm}$, under vacuum. The second, using a cellulose membrane $(0.22 \mu \mathrm{m})$. The resulting liquid was sterilized in an autoclave and incorporated in PDA culture medium at a proportion of $25 \%(\mathrm{v} / \mathrm{v})$, based on the method described by Isaias et al. (2014).

The assay was conducted using a completely randomized block design and five repetitions, including the following treatments: T1-sterilized cell suspension of BRM 32111; T2-sterilized cell suspension of BRM 32112; T3- BRM 32111 filtrate; T4- BRM 32112 filtrate; T5-sterilized BRM 32111 filtrate; T6-sterilized BRM 32112 filtrate; T7-M. oryzae (control).

\section{Greenhouse experiment}

The cultivar BRS Primavera was sown in plastic trays $(15 \times 30 \times 10 \mathrm{~cm})$ containing $3 \mathrm{~kg}$ of soil, fertilized with $5.0 \mathrm{~g}$ of NPK (5-30-15). Twenty days after planting, $3 \mathrm{~g}$ of ammonium sulfate was applied as a top dressing. The conidial suspension of $M$. oryzae was made according to Filippi et al. (2011). The conidial suspension was adjusted to $3 \times$ $10^{5} \mathrm{~mL}^{-1}$.

\section{Filtrated co-cultures of bacterial isolates and $M$. oryzae}

The isolates BRM 32111 and BRM 32112 were selected based on the results from the in vitro assays. One milliliter of bacterial suspension $\left(10^{8}\right.$ ufc $\mathrm{ml}^{-1}$ ) was transferred to Simmons liquid culture medium containing $3 \times 10^{5}$ conidia $\mathrm{mL}^{-1}$ of $M$. oryzae and kept in a shaker for 10 days. After centrifuging the resulting solutions, the supernatant was filtered using Whatman, $n^{\circ} 4$ under vacuum.

Rice plants, at the V3 growth stage, were sprayed until the point of dripping, with a suspension containing conidia $\left(3 \times 10^{5} \mathrm{~mL}^{-1}\right.$ at final concentration) of $M$. oryzae mixed with: T1-control (water), T2-cell suspension of BRM 32111, T3- cell suspension of BRM 32112, T4-filtrate of BRM 32112, T5-filtrate BRM 32111, T6- filtrate of BRM $32111+M$. oryzae conidia, T7- filtrate of BRM $32112+M$. oryzae. After spray inoculations, the plants were incubated at temperatures varying from 28 to $30{ }^{\circ} \mathrm{C}$ at high humidity.

\section{RESULTS AND DISCUSSION}

\section{Morphological and biochemical characterizations of the bacterial isolates}

The morphological characteristics of all six isolates are presented in Table 1. BRM 32112 was the only isolate to fluoresce. BRM 32109 and BRM 32110 were Gram positive, and BRM 32111, 32112, 32113, and 32114 were Gram negative. The biochemical characteristic analyses showed that all six isolates produced cellulose and phosphatases, and that none produced chitinase. Only BRM 32110 did not produce siderophores, BRM 32113 and BRM 32114 produced AIA, and BRM 32111 and BRM 32112 produced biofilms.

Table 1. Morphological and biochemical characterization of bacterial isolates

\begin{tabular}{lcccccc}
\hline \multirow{2}{*}{ Characteristics } & \multicolumn{5}{c}{ Isolates BRM } \\
\cline { 2 - 7 } & 32113 & 32111 & 32114 & 32112 & 32110 & 32109 \\
\hline Color & Rose & yellow & cream/rose* & white & white & white \\
Opaqueness & translucent & translucent & translucent & translucent & opaque & opaque \\
Form & Circular & circular & Circular** & circular & circular & circular \\
Margin & smooth & smooth & smooth & smooth & irregular & irregular \\
Elevation & convex & undulated & elevated & convex & undulated & flat \\
\hline
\end{tabular}

*Initially the colonies were in cream color and later changed to pink after 5 days.

**Circular with elevated margins. 
The principal component analysis (PCA) (Figure 1) showed that only the isolates BRM 32113 and 32114 were positively correlated with IAA production. All six isolates were positively correlated with celullase and phosphatase production. Only BRM 32111 and BRM 32112 were positively correlated with fluorescence and biofilm production, while BRM 32110 was negatively correlated with siderophore production.

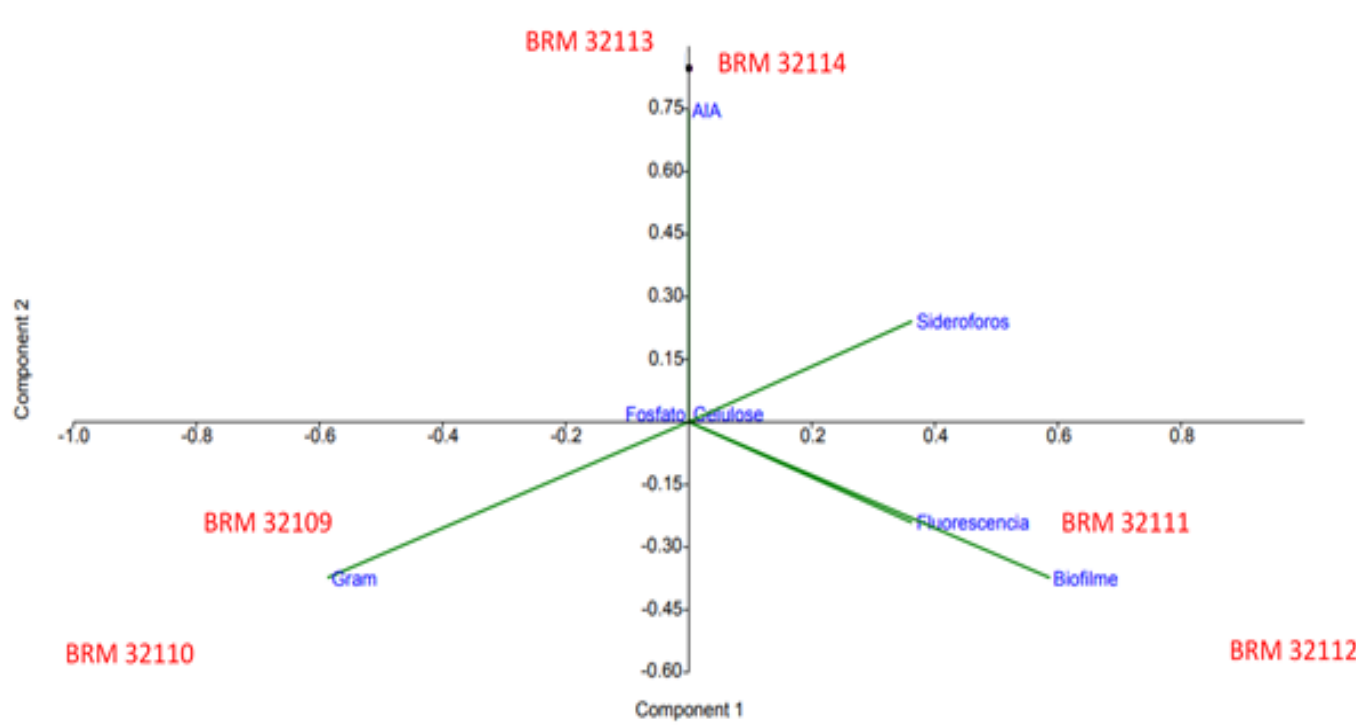

Figure 1. Principal component analysis (PCA) of bacterial isolates based on Euclidean coefficient of similarity among biochemistry.

\section{Identification of isolates using PCR}

The molecular characterizations of the bacterial isolates by partial sequencing of their $16 \mathrm{~S}$ rRNA (fragments of 600-700 base pairs) revealed the following matches: BRM 32111 was a P. fluorescens Migula, BRM 32113 was a Burkholderia sp., BRM 32114 was a Serratia sp., BRM 32112 was a Pseudomonas sp., and BRM 32109 and BRM 32110 were Bacillus sp (Table 2).

Table 2. Molecular characterization of bacterial isolates by partial sequencing of the 16S rRNA region (fragments of approximately $600-700$ base pairs).

\begin{tabular}{lcc}
\hline Isolate & NCBI* & GeneBank accession number \\
\hline BRM 32111 & Pseudomonas fluorescens & MT188711 \\
BRM 32113 & Burkholderia sp & MT188713 \\
BRM 32114 & Serratia sp. & KX 378747 \\
BRM 32112 & Pseudomonas sp. & MT188712 \\
BRM 32109 & Bacillus sp. & MT188714 \\
BRM 32110 & Bacillus sp. & KX378746 \\
\hline
\end{tabular}

*National Center for Biotechnology Information.

\section{In vitro antagonism between bacterial cell suspensions and M. oryzae}

All isolates statistically inhibited the mycelial growth of $M$. oryzae. The best results were observed with the BRM 32111, BRM 32112, and BRM 32113 isolates, as they inhibited colony growth by $68 \%$, $65 \%$, and $48 \%$, respectively, when compared to the control treatment. (Figure $2 \mathrm{~A}$ ).

\section{In vitro antagonism between filtrates of bacterial isolates and M. oryzae}

Treatments T1, filtrate from BRM 32112 and T2, and filtrate from BRM 32111 inhibited $M$. oryzae colony growth the most, when compared to the control. Filtrates obtained from co-cultivations of M. oryzae and BRM 32112 (T3) and BRM 32111 (T4) did not inhibited $M$. oryzae colony growth presented the best inhibition (Figure 2B). 

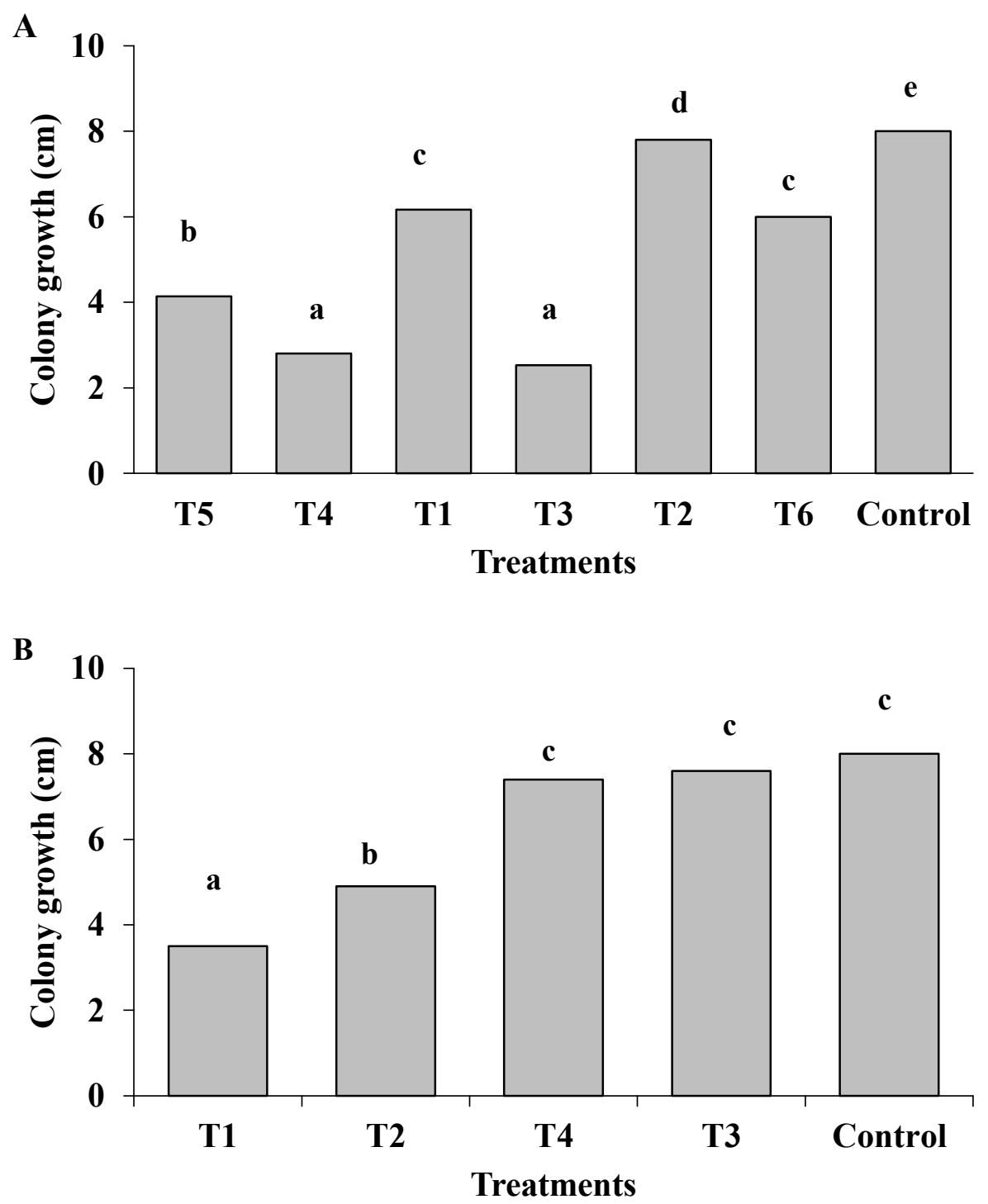

Figure 2. Inhibition growth of Magnaporthe oryzae colony by 6 bacterial cell suspensions and 4 filtrates. A: Antagonism between M. oryzae and BRM 32110 (T1), BRM 32109 (T2), BRM 32112 (T3), BRM 32111 (T4), BRM 32113 (T5), and BRM 32114 (T6); control (no bacterial suspension). B: M. oryzae growth in medium supplemented with: BRM 32112 filtrated (T1), BRM 32111 filtrated (T2), filtrated of co-culture of M. oryzae and BRM 32112 (T3), and filtrated of coculture of M. oryzae and BRM 32111 (T4) and water (control). Bars with the same letter do not differ statistically by Duncan test $(\mathrm{p}<0.05)$.

\section{The efficiency of bacterial isolates and respective filtrates on leaf blast suppression}

The treatments $\mathrm{T} 2, \mathrm{~T} 3, \mathrm{~T} 4, \mathrm{~T} 5$ and $\mathrm{T} 7$ statistically suppressed disease severity when compared to T1 and T6 (Figure 3).

Strategies to maintain and enhance agricultural productivity include high input practices, such as fertilizers and defensives. With climate change, the major influencing factor will be the availability and management of soil water and extreme temperature events, such as heatwaves and droughts, which decrease the annual recharging of soil and groundwater levels (YADAV et al., 2007). In this sense, microbial diversity in the rhizosphere, rhizoplane, and phyllosphere could assecure the sustainability of agricultural production systems.

In the present study, BRM 32111 and BRM 32112 were identified as Pseudomonas sp., BRM 32113 as Burkholderia sp., BRM 32114 as Serratia sp. and BRM 32110 and BRM 32109 as Bacillus spp. (Table 2).

Our results present six bacterial isolates classified according to colony characteristics and Gram stain (Table 1). Cabeen and Jacobs-Wagner (2005) emphasized the importance of describing and classifying bacterial species based on cultural characteristics complemented with biochemical and molecular characterizations (Table 1). The sequencing of the $16 \mathrm{~S}$ rRNA region has been widely utilized, by several authors, to identify bacterial 
genera (LOCATELLI et al., 2002; WAHYUDI et al., 2011; SOUZA et al., 2013). The genetic plasticity of bacteria that permits DNA transfer through plasmids, bacteriophages, and transposons complicates the identity of bacterial species (FEDRIZZI, 2006), and for this reason, the methods for studying soil bacterial diversity can be divided into biochemical and molecular techniques.

A

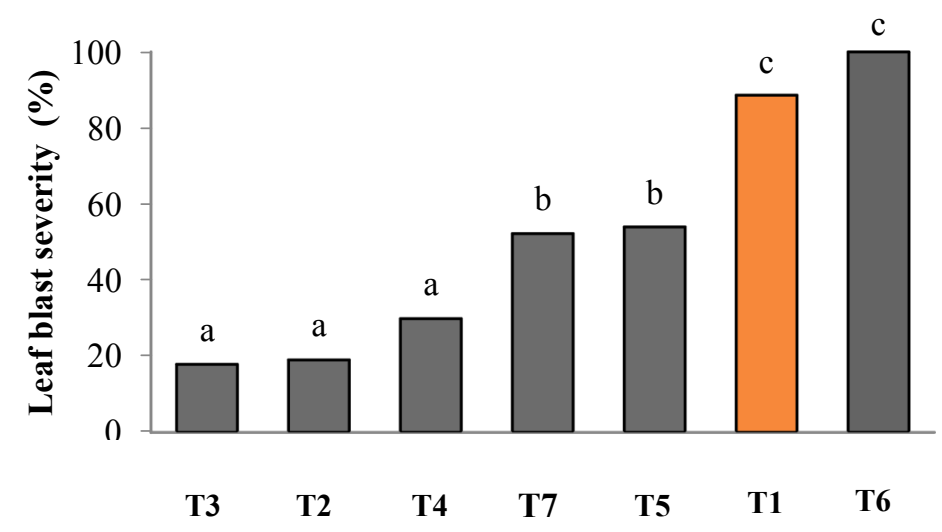

B

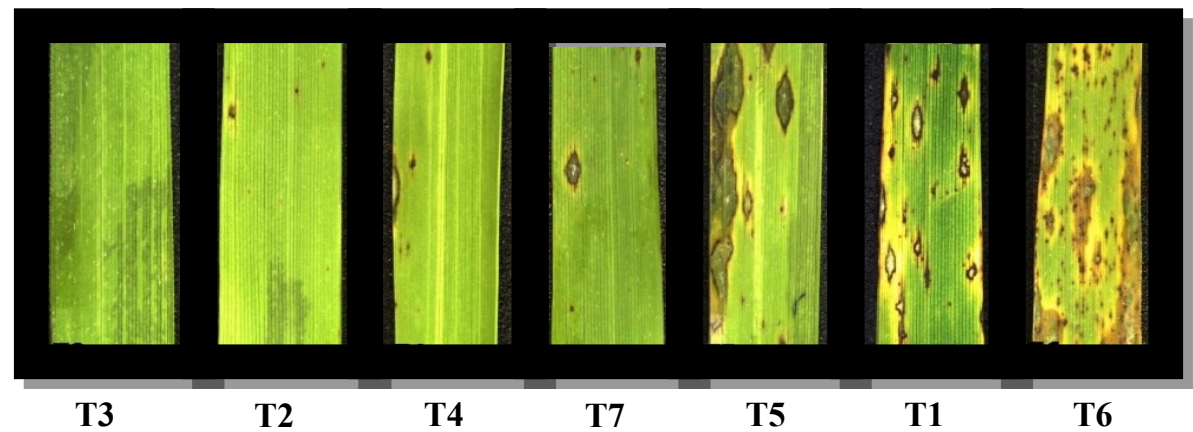

Figure 3. Leaf blast suppression by BRM3211 and BRM 32111 cell suspensions and filtrates. A: Leaf blast severity after spray inoculation of M. oryzae (Mo) suspension mixed with: T1: control (water); T2: BRM 32111 cell suspension; T3: BRM 32112 cell suspension, T4: filtrate of BRM 32112, T5: filtrate BRM 32111, T6: filtrate of co-culture of BRM $32111+$ Mo; T7: filtrate of co-culture of BRM $32112+$ Mo. B: Rice leaf blast typical symptoms, rinsing from pin-like lesions (T3) to typical susceptible lesion (T6). Bars with the same letter did not differ according to Duncan test (p < $0.05)$.

The BRM 32113 and BRM 32114 isolates were identified as indole acetic acid (IAA) producers, confirming the previous results obtained, showing that BRM 32113 and BRM 32114 (Figure 1) can promote plant growth. When active in the root systems, they can increase the size and number of ramifications of adventitious roots, and the contact area with the soil, making considerable quantities of nutrients available to the plant. In turn, rhizobacteria benefit from higher levels of root exudates. The application of biological inducers, with the capacity to promote the initial growth of seedlings, constitutes a viable alternative for a no-tillage production system (SPERANDIO et al., 2017). Rice seeds treated with BRM 32113 and BRM 32114 resulted in rice shoots with a biomass increase of 70\% (FILIPPI et al., 2011; NASCENTE et al., 2017; SPERANDIO et al., 2017).

Of the six isolates investigated, BRM 32113,
BRM 32111, BRM 32112, BRM 32110, and BRM 32114 were all identified as siderophore producers (Table 1). The soil microorganisms usually compete for nutrients of low availability. One mechanism that confers an advantage in this competition is the production of siderophores that are capable of forming $\mathrm{Fe}^{3+}$ complexes (HALFELD-VIEIRA et al., 2015). It is important to emphasize that, when the Fe levels are low in the soil, siderophores can be produced (CATTELAN, 1999). Siderophore producing isolates are fundamentally important for the Cerrado biome. According to Fageria, Moreira and Coelho (2001), soil quality in the West-Central region of Cerrado is naturally acidic and requires the addition of micronutrients such as iron $(\mathrm{Fe})$. The adoption of siderophore producing rhizobacteria into the integrated management of rice diseases, permits the coating of plant roots with $\mathrm{Fe}$ and protects against plant pathogens (GRAY; SMITH, 2005; 
SOLANKI et al., 2014; NAUREEN et al., 2015). Plant pathogens are sensitive to the actions of siderophores produced by antagonists due to their low affinity for iron (MELO, 1998).

Only BRM 32112 and 32111 formed biofilms (Table 1), which correlates with the results of Rêgo et al. (2014). This is an essential characteristic for successful interactions between plants and rhizobacterium. According to Recouvreux (2004), this structure constitutes a form of protection that permits microorganisms to survive in an adverse environment. Spaepen, Vanderleyden and Okon (2009) showed that quorum sensing is involved in processes such as virulence, symbiosis maturation of biofilms, mobility, and survival of bacteria. They concluded that $\mathrm{pH}$, iron level, and availability of nutrients are essential modulators of biofilm production.

Finally, the principal component analysis (PCA) revealed the correlations between the biochemical and morphological characteristics observed in this investigation, to complement the genetic characterizations (Figure 1). It is essential to emphasize the importance of a broad approach to integrate the different data and information obtained from the bacteria, since this polyphase called "taxonomy", allows us to affirm that one test complements the other. The molecular identification and biochemical tests were all highly correlated.

The BRM 32111 and BRM 32112 isolates were markedly distinct as antagonists of $M$. oryzae, inhibiting pathogen growth in vitro (Figure 3). Microorganisms that act by antibiosis, generally, possess a broad spectrum of action. In the inhibition process of fungi, the production of toxic substances is more effective than any other mechanism involved (KUPPER; GIMENES-FERNANDES; GOES, 2003). Similar results were obtained by Amorim and Melo (2002) when they investigated antagonism between different rhizobacteria isolates and Phytophthora parasitic, as seven bacterial isolates were found to be capable of inhibiting the mycelial growth of the pathogen. The authors concluded that antagonism must occur by both siderophore production as well as by toxic substances of the pathogen (antibiosis).

In vitro, the selected filtrates (BRM 32112, and BRM 32111) inhibited $M$. oryzae mycelial growth (Figure 2). Besides, these two isolates significantly suppressed leaf blast in tests conducted in the greenhouse. The T2 (suspension BRM 32111 + M. oryzae), T3 (suspension BRM $32112+M$. oryzae), and T4 (filtrate BRM $32112+$ M. oryzae) treatments suppressed leaf blast, when compared with the control, by $81.0 \%, 79.2 \%$, and $66.3 \%$, respectively (Figure 3). For the T1 (control) and T6 (suspension BRM $32111+$ Mo (filtrate of cocultivation) $+M$. oryzae) treatments, the lesions were typically elliptical with brown margins and grey centers, sporulating, and coalescing to occupy more than $50 \%$ of the leaf area. Treatments T2 (suspension BRM 32111), T3 (suspension BRM 32112), and T4 (filtrate BRM 32112) resulted in small brown pinhead sized necrotic, non-sporulating lesions. T5 (filtrate BRM 32111) resulted in prominent elliptical lesions that were a few millimeters in diameter with necrotic centers and brown margins, some coalescing on the leaf margins was observed. T7 (filtrate of co-cultivation of BRM $32112+$ Mo) resulted in elliptical slightly elongated lesions with brown margins, yellow halos, and grey centers. Some researchers have suggested the use of substances derived from the metabolism of rhizobacteria to control fungal diseases (CATTELAN, 1999; KUPPER; GIMENESFERNANDES; GOES, 2003; BETTIOL; MORANDI, 2009). The Pseudomonas spp. have a high capacity to suppress soil pathogens, are nutritionally versatile, and possess the ability to grow in a wide range of environmental conditions, besides producing high quantities of antibiotics, siderophores, and plant growth hormones. The mechanisms of action of this group include the production of antibiotic compounds, as they act directly to suppress pathogens. In the present study, the partial sequencing of the 16S rRNA genes of the BRM 32111 and BRM 32112 isolates showed a similarity to the Pseudomonas genus and they were found to be efficient both in in vitro antagonism (Figure 2) as well as in vivo suppression of rice leaf blast (Figure 3).

There have been several previous investigations on the inhibitory effects of bacteria from the genus Pseudomonas, on the growth of fungi. For example, Jousset et al. (2006) investigated the antifungal activity of 30 fluorescens isolates against the main rice pathogens. The authors identified an isolate capable of inhibiting the mycelial growth of all pathogens. They proceeded to extract the compounds produced by this single isolate, and they were also found to inhibit the growth of the same pathogens. After isolating and purifying one of the compounds called 2,4diacetylfloroglucinol (DAPG), it was also found to inhibit the growth of all rice pathogens.

Bajpai et al. (2018), showed that several types of antifungal compounds that are secreted by Pseudomonas sp. have been characterized as secondary metabolites, including 2,4-DAPG, pyoluteorin, phenazines, and pyrrolnitrin. Rhizospheric bacteria depend upon root exudates as carbon and nitrogen sources to produce secondary metabolites. The same secondary metabolites produced by bacterial cells were possibly responsible for inhibiting $M$. oryzae growth and suppressing rice plant colonization. 


\section{CONCLUSION}

According to Dean et al. (2012), M. oryzae fungus was ranked as one of the top 10 fungal pathogens in the world. As more than half of the world's population relies on rice as their primary source of energy, M. oryzae can have devastating economic effects on rice cultivation, threatening food security. The approach presented here allows for the search of alternative disease control measures in agriculture to be intensified, such as for example, the use of biocontrol agents. Biological controls, when combined with integrated management techniques, may lead to the developmenmt of sustainable disease control strategies.

Agricultural practices are currently facing many challenges, such as soil impoverishment due to degradation processes such as erosion, salinization, pollution, or biological degradation, which have all become intensified in recent years. Thus, maintaining and restoring soil fertility through a rational fertilization plan should be part of any program of agricultural activity (SILVA FILHO; NARLOCH; SCHARF, 2002). BRM 32111 and BRM 32112 were identified as phosphatase, cellulose, and siderophores producers.

The results show that the bacterial isolates BRM 32111 and BRM 32112 were identified as Pseudomonas sp., and could potentially, be highly effective at controlling rice blast. Further research regarding the utilization of these two isolates as components of integrated disease management of upland rice is ongoing. Arriel-Elias et al. (2018, 2019) have developed a sustainable formulation for BRM 32111 bacterial isolate, presenting a viable prototype for commercial scale use under field conditions, to reduce production costs, pollution, and hazards to human health.

\section{REFERENCES}

ALTSCHUL, S. F. et al. Basic local alignment search tool. Journal of molecular biology, 215: 403 $-410,1990$.

ARRIEL-ELIAS, M. T. et al. Shelf life enhancement of PGPRs using a simple formulation screening method. African Journal of Microbiology Research, 12:115-125, 2018.

ARRIEL-ELIAS, M.T. et al. Induction of resistance in rice plants using bioproducts produced from Burkholderia pyrrocinia BRM 32113. Environmental Science and Pollution Research, 26: 19705-19718, 2019

AMORIM, E. P. R.; MELO, I. S. Ação antagônica de rizobactérias contra Phytophthora parasitica e $P$. citrophthora e seu efeito no desenvolvimento de plântulas de citros. Revista Brasileira de Fruticultura, 24: 565-568, 2002.

ASIAH, N. et al. Review on pesticide residue on rice. In: 2018 INTERNATIONAL CONFERENCE ON FOOD SCIEN AND TECHNOLOGY (FOSCItECH). Proccedings... IOP Conf. Series: Earth and Environmental Science, IOP Publishing, 2019 , Vol. 379.

BAJPAI, A. et al. Production and Characterization of an Antifungal Compound from Pseudomonas protegens Strain W45. National Academy of Sciences, India, Section B: Biological Sciences, 88: 1081-1089, 2018.

BENSON, H. J. Microbiological applications: laboratory manual in general microbiology: complete version. 8. ed. New York, NJ: McGrawHill, 2002. 478 p.

BETTIOL, W.; MORANDI, M. A. B. Biocontrole de doenças de plantas: uso e perspectivas. 1 ed. Jaguariúna, SP: Embrapa Meio Ambiente, 2009, 341 p.

BRIC, J. M.; BOSTOCK, R. M.; SILVERSTONE, S. E. Rapid in situ assay for indoleacetic acid production by bacteria immobilized on a nitrocellulose membrane. Applied and Environmental Microbiology, 57: 535-538, 1991.

CABEEN, M. T.; JACOBS-WAGNER, C. Bacterial cell shape. Nature Reviews Microbiology, 3: 601610,2005

CATTELAN, A. J. Métodos qualitativos para determinação de características bioquímicas e fisiológicas associadas com bactérias promotoras do crescimento vegetal. Londrina, PR: Embrapa Soja, 1999. 36 p.

DEAN, R. et al. The Top 10 fungal pathogens in molecular plant pathology. Molecular plant pathology, 13: 414-430, 2012.

DENNIS, C.; WEBSTER, J. Antagonistic properties of species-groups of Trichoderma: II. Production of volatile antibiotics. Transactions of the British Mycological Society, 57: 41-48, 1971.

FAGERIA, N. K., MOREIRA, A., COELHO, A. M. Yield and yield components of upland rice as influenced by nitrogen sources. Journal of Plant Nutrition. 34: 361-370. 2001.

FEDRIZZI, S. M. G. Produção de metabólitos antimicrobianos e sideróforos isolados provenientes de Terra Preta Antropogênica da 
Amazônia Ocidental. 2006. 117 f. Tese (Doutorado em Ciências: Área de concentração em Biologia na Agricultura e no Ambiente) - Universidade de São Paulo, Piracicaba, 2006.

FILIPPI, M. C. C. et al. Leaf Blast (Magnaporthe oryzae) suppression and growth promotion by rhizobacteria on aerobic rice in Brazil. Biological Control, 58: 160-166, 2011.

GORDON, S. A.; WEBER, R. P. Colorimetric estimation of indoleacetic acid. Plant Physiology, 26: 192-195, 1951 .

GRAY, E.; SMITH, D. Intracellular and extracellular PGPR: commonalities and distinctions in the plantbacterium signaling processes. Soil Biology and Biochemistry, 37: 395-412, 2005.

HALFELD-VIEIRA, B. A. et al. Understanding the mechanism of biological control of passionfruit bacterial blight promoted by autochthonous phylloplane bacteria. Biological Control, 80: 40-49, 2015.

HAMMER, Ø.; HARPER, D.; RYAN, P. PAST: Palaeontological statistics. Disponível em: <https:// www.uv.es/pardomv/pe/2001_1/past/pastprog/ past.pdf $>$. Acesso em: 23 out. 2019 .

HASSAN, E.; HOSSEIN A. A.; HOSSEIN, M. H. Root bacterial endophytes as potential biological control agents against fungal rice pathogens. Archives of phytopathology and plant protection, 52: 560-581, 2019.

HEUER, H. et al. Analysis of actinomycete communities by specific amplification of genes encoding 16S rRNA and gel-electrophoretic separation in denaturing gradients. Applied and environmental Microbiology, 63: 3233-3241, 1997.

HSU, S. C.; LOCKWOOD, J. L. Powdered chitin agar as a selective medium for enumeration of actinomycetes in water and soil. Applied microbiology, 29: 422-426, 1975.

ISAIAS, C. O. et al. Ação antagônica e de metabólitos bioativos de Trichoderma spp. contra os patógenos Sclerotium rolfsii e Verticillium dahliae. Summa Phytopathological, 40: 34-41, 2014.

JOUSSET, A. et al. Secondary Metabolites Help Biocontrol Strain Pseudomonas fluorescens CHA0 To Escape Protozoan Grazing. Applied and Environmental Microbiology, 72: 7083-7090, 2006.

KADO, C.; HESKETT, M. Selective media for isolation of Agrobacterium, Corynebacterium,
Erwinia, Pseudomonas, and Xanthomonas Phytopathology, 60: 969-976, 1970.

KUPPER, K. C.; GIMENES-FERNANDES, N.; GOES, A. Controle biológico de Colletotrichum acutatum, agente causal da queda prematura dos frutos cítricos. Fitopatologia Brasileira, 28: 251$257,2003$.

LI, X.; BOUER, S. H. D. Selection of polymerase chain reaction primers from an RNA intergenic spacer region for specific detection of Clavibacter michiganensis subsp. sepedonicus. Phytopathology, 85: 837-842, 1995

LOCATELLI, L. et al. Specific PCR amplification for the genus Pseudomonas targeting the $3^{\prime}$ half of $16 \mathrm{~S}$ rDNA and the whole 16S-23S rDNA spacer. Systematic and applied microbiology, 25: 220-227, 2002.

MARIANO, R. L. R. et al. Importância de bactérias promotoras de crescimento e de biocontrole de doenças de plantas para uma agricultura sustentável. Anais da Academia Pernambucana de Ciência Agronômica, 1: 89-111, 2004.

MATHUR, T. et al. Detection of biofilm formation among the clinical isolates of staphylococci: an evaluation of three different screening methods. Indian Journal of Medical Microbiology, 24: 25 29, 2006.

MELO, I. S. Rizobactérias Promotoras de Crescimento em Plantas: Descrição e potencial de uso na agricultura. IN: MELO, I. S.; AZEVEDO, J. L. (Eds.). Ecologia microbiana. Jaguariúna: Embrapa-CNPMA, 1998. v. 1, cap. 3, p. 87-116.

MOREIRA, M. S. F.; SIQUEIRA, J. O. Microbiologia e bioquimica do solo. 2. Ed. Lavras, MG: UFLA, 2002, 626 p.

NASCENTE, A. S. et al. Biomass, gas exchange, and nutrient contents in upland rice plants affected by application forms of microorganism growth promoters. Environmental Science and Pollution Research, 24: 2956-2965, 2017.

NAUREEN, Z. et al. Suppression of incidence of Rhizoctonia solani in rice by siderophore producing rhizobacterial strains based on competition for iron biocontrol of sheath blight in rice. European Scientific Journal, 11: 186-207, 2015.

PEREIRA FILHO, C. R. Seleção e aplicação de rizobactérias promotoras de crescimento e indutoras de resistência sistêmica em arroz (Oryza sativa) de terras altas. 2013. $101 \mathrm{f}$. Dissertação (Mestrado em Agronomia: Área de 
concentração em Fitossanidade) - Universidade Federal de Goiás, Goiânia, 2013.

PRABHU, A. S.; FARIA, J. C.; ZIMMERMANN, F. J. P. Comparative yield loss estimates due to blast in some upland rice cultivars. Fitopatologia Brasileira, 14: 227-232, 1989.

RATHNA, P. T. S. et al. Nutritional and functional properties of coloured rice varieties of South India: a review. Journal of Ethnic Foods, 6: 7-11, 2019.

NISHIMOTO, R. Global trends in crop industry. Journal Pesticide Science, 44: 141-147, 2019.

RECOUVREUX, D. D. O. S. Produção de celulose bacteriana: identificação do operon bcs e produção de biofilme celulósico por Chromobacterium violaceum. 2004. 124 f. Dissertação (Mestrado em Engenharia Química: Área de concentração em Engenharia Genômica e Engenharia Biomédica) - Universidade Federal de Santa Catarina, Flrianópolis, 2004.

RÊGO, M. C. F et al. Morphoanatomical and Biochemical Changes in the Roots of Rice Plants Induced by Plant Growth-Promoting Microorganisms. Journal of Botany, 2014: 1-10, 2014.

RICEPEDIA. The online authority on rice. Disponível em: <http://ricepedia.org/challenges/food -security>acesso em: 15 abri. 2020.

SILVA FILHO, G. N.; NARLOCH, C.; SCHARF, R. Solubilização de fosfatos naturais por microrganismos isolados de cultivos de Pinus e Eucalyptus de Santa Catarina. Pesquisa agropecuária brasileira, 37: 847-854, 2002.

SIMMONS, J. S. A culture medium for differentiating organisms of typhoid-colon aerogenes groups and for isolation of certain fungi. The Journal of Infectious Diseases, 39: 209-214, 1926.

SOLANKI, M. K et al. Isolation and characterization of siderophore producing antagonistic rhizobacteria against Rhizoctonia solani. Journal of Basic Microbiology, 54: 585-597, 2014.

SOUZA, R et al. The effect of plant growthpromoting rhizobacteria on the growth of rice (Oryza sativa L.) cropped in southern Brazilian fields. Plant and soil, 366: 585-603, 2013.

SPAEPEN, S.; VANDERLEYDEN, J.; OKON, Y. Plant growth-promoting actions of rhizobacteria. Advances in botanical research, 51: 283-320, 2009.
SPERANDIO, E. $\mathrm{M}$ et al. C. Evaluation of rhizobacteria in upland rice in Brazil: growth promotion and interaction of induced defense responses against leaf blast (Magnaporthe oryzae). Acta Physiologiae Plantarum, 39: 259, 2017.

STRAUSS, M. et al.. Screening for the production of extracellular hydrolytic enzymes by non Saccharomyces wine yeasts. Journal of Applied Microbiology, 91: 182-190, 2001.

SYLVESTER-BRADLEY, R. et al.. Levantamento quantitativo de microrganismos solubilizadores de fosfatos na rizosfera de gramíneas e leguminosas forrageiras na Amazônia. Acta Amazônica, 12: 15$22,1982$.

TALBOT, N. J. On the trail of a cereal killer: exploring the biology of Magnaporthe grisea. Annual Review Microbiology, 57: 177-202. 2003.

WAHYUDI, A. T. et al. Characterization of Bacillus sp. strains isolated from rhizosphere of soybean plants for their use as potential plant growth for promoting rhizobacteria. Journal of Microbiology and Antimicrobials, 3: 34-40, 2011

WALITANG, D. et al. Diversity and Plant GrowthPromoting Potential of Bacterial Endophytes in Rice. In: SAYYED R., REDDY M., ANTONIUS S. (Eds) Plant Growth Promoting Rhizobacteria (PGPR): Prospects for Sustainable Agriculture. Singapore: Springer, 2019 p. 3-17.

WIDIANTINI, A.; HERDIANSYAH, A.; YULIA, E. Biocontrol Potential of Endophytic Bacteria Isolated from Healthy Rice Plant against Rice Blast Disease (Pyricularia oryzae Cav.). KnE Life Sciences, 2: 287-295, 2017.

YADAV, R. K. et al. Fodder production and soil health with conjunctive use of salineand good quality water in ustipsamments of a semi aridregion. Land Degradation \& Development, 18: 153-161, 2007. 